\title{
Type 2 Diabetes Mellitus and Alzheimer's Disease: Role of Insulin Signalling and Therapeutic Implications
}

\author{
Andrea Tumminia, Federica Vinciguerra, Miriam Parisi and Lucia Frittitta * (D) \\ Endocrinology, Department of Clinical and Experimental Medicine, University of Catania, Diabetes, \\ Obesity and Dietetic Center, Garibaldi Hospital, Via Palermo n ${ }^{\circ} 636,95122$ Catania, Italy; \\ andreatumminia@libero.it (A.T.); vinciguerrafederica@gmail.com (F.V.); mrmparisi@gmail.com (M.P.) \\ * Correspondence: lfritti@unict.it
}

Received: 24 September 2018; Accepted: 18 October 2018; Published: 24 October 2018

\begin{abstract}
In the last two decades, numerous in vitro studies demonstrated that insulin receptors and theirs downstream pathways are widely distributed throughout the brain. This evidence has proven that; at variance with previous believes; insulin/insulin-like-growth-factor (IGF) signalling plays a crucial role in the regulation of different central nervous system (CNS) tasks. The most important of these functions include: synaptic formation; neuronal plasticity; learning; memory; neuronal stem cell activation; neurite growth and repair. Therefore; dysfunction at different levels of insulin signalling and metabolism can contribute to the development of a number of brain disorders. Growing evidences demonstrate a close relationship between Type 2 Diabetes Mellitus (T2DM) and neurodegenerative disorders such as Alzheimer's disease. They, in fact, share many pathophysiological characteristics comprising impaired insulin sensitivity, amyloid $\beta$ accumulation, tau hyper-phosphorylation, brain vasculopathy, inflammation and oxidative stress. In this article, we will review the clinical and experimental evidences linking insulin resistance, T2DM and neurodegeneration, with the objective to specifically focus on insulin signalling-related mechanisms. We will also evaluate the pharmacological strategies targeting T2DM as potential therapeutic tools in patients with cognitive impairment.
\end{abstract}

Keywords: insulin receptor; insulin signalling; neurodegenerative disorders; Alzheimer's disease; type 2 diabetes mellitus

\section{Introduction}

The brain was once thought to be an insulin-insensitive organ. However, it is now widely recognized that insulin plays an important role in neuronal survival and brain function. Insulin action is, in fact, required for neuronal synaptic plasticity and facilitates learning and memory [1]. It has also been shown that insulin promotes dendritic spine and synapse formation, neuronal stem cell activation, neurite growth and repair and neuroprotection [2]. Therefore, alterations in insulin metabolism and signalling in the Central Nervous System (CNS) can contribute to the development of many brain disorders.

Over the past 20 years, many studies have shown an association between neurodegenerative disorders such as Alzheimer's Disease (AD) and impaired insulin signalling in CNS [3,4], suggesting that reduced insulin action and insulin resistance might play an important role, through different mechanisms, in the pathogenesis of these brain disorders.

Following, we will review the main pathophysiological connection between AD and T2DM, highlighting the role of dysfunctional insulin transduction pathway in the determinism of neurodegeneration. We will focus on the role of insulin signalling in the crucial hallmarks of AD-related damage: deposition of neuritic plaques, formation of intracellular neurofibrillary tangles (NFTs), vasculopathy and inflammation-related damage. 
We will also evaluate the pharmacological treatments targeting type 2 diabetes (T2DM) as potential therapeutics for preventing neurodegeneration and cognitive decline.

\section{Overview of Insulin Signalling}

Insulin and Insulin-Like-Growth-Factor (IGF)-1 regulate several biological processes through the binding and activation of two closely related tyrosine kinase receptors, the Insulin Receptor (IR) and the IGF-1 receptor (IGF-1R) [5]. Several studies have demonstrated that IR and IGF-1R, as well as their common downstream pathways, are widely distributed within the brain and, more importantly, these pathways function as regulators of neurogenesis, brain function and whole-body energy balance and metabolism [3]. The highest concentration of IR is in the hypothalamus, hippocampus, in the olfactory bulb, cerebellum, amygdala and cerebral cortex [6]. The wide spectrum of insulin receptors' location within the CNS indicates multi-functionality of insulin [3].

Insulin is a large peptide hormone that cannot passively pass through the blood-brain barrier (BBB) but it is still found in the cerebrospinal fluid (CSF). The origin of "brain" insulin is controversial. One possibility is that plasma insulin is able to cross the BBB via a saturable transport process, possibly the IR on vascular endothelium. Supporting this hypothesis is the evidence that insulin levels in the CSF are lower (about $25 \%$ less) of those circulating in blood and its concentrations increase after meals or with peripheral insulin infusion [7]. Another possibility is the evidence that there are regions of the brain, such as the hypothalamus, that lack an effective barrier, allowing insulin access to CNS [8]. A third hypothesis suggests that insulin is synthesized in the brain regions but this possibility requires further studies [3,9].

After reaching the CNS insulin binds to the IR, which belongs to the family of tyrosine kinase receptors. Interestingly, IR subunits found in the brain have different structure to those of the periphery and the main difference is a lower molecular weight of brain IR subunits probably due to different glycosylation [10]. Moreover, the brain expresses predominantly the A isoform (-exon 11) of the IR, which has a higher affinity for IGF-2, in contrast to the peripheral tissues which express predominantly the B isoform (+exon 11) [11,12].

Insulin is suggested to have neuroprotective properties and to exert neurotrophic effects on CNS neurons [13]. Moreover, it could positively influence emotion and higher cognitive processes including attention, executive functioning, learning and memory [14].

After insulin binding to the IR, auto-phosphorylation of the receptor occurs and the activated IR phosphorylates a cascade of IR substrate proteins (Figure 1) [5]. Among the IR substrates (IRSs), IRS-2 mRNA in the brain is most abundant compared with IRS-1; IRS-4, which is mainly expressed in embryonic development, is also expressed in the brains of adult mice, especially the hypothalamus $[3,15]$. At the whole-body level, IRS-1 appears to be critical for growth and IRS-1-null mice result in an increased brain-to-body ratio [16]. On the other hand, disruption of IRS-2 gene reduces neuronal proliferation during development by $50 \%$ and as a consequence IRS-2-null mice exhibit a reduced brain-to-body ratio [17]. In addition, during aging, neurofibrillary tangles containing phosphorylated tau accumulated in the hippocampus of IRS-2 knockout mice, suggesting that IRS-2 signalling is neuroprotective [17]. Despite this, IRS-2-null mice are long lived [18], consistent with a role of central insulin/IGF signalling in control of life span in mammals. IRS-4 may synergistically cooperate with IRS-2 in the hypothalamus to control food intake, energy expenditure and glucose metabolism [19].

The specific inactivation of IR in the brain (i.e., neuron-specific IR knockout-NIRKO-mice), showed that lack of IR in brain determine an altered metabolic phenotypes, including diet-sensitive obesity, increased body fat and insulin resistance while did not affect brain size and development, suggesting that IR signalling in the CNS plays an important role in regulation of energy disposal and fuel metabolism $[3,20]$. Moreover, insulin resistance in the brain exists as a distinct phenomenon, independent of peripheral insulin resistance and glucose intolerance [21,22]. It implies that diminished responsiveness to insulin in the brain has different consequences than in peripheral tissues. Recent published data showed that peripheral insulin and glucose tolerance were comparable between 
aged wild type and APP/PS1 mice (a model of AD), while levels of serine phosphorylated IRS-1 were increased in the brain of APP/PS1 mice [23]. This provides some support for the suggestion that insulin resistance in brain may indeed exist as a distinct phenomenon, separate from insulin signalling in the periphery and one that can distinguish AD-related neurodegeneration from normal aging.

One of the major downstream pathways of IRS proteins is the PI3K/Akt cascade. This, in turn, targets multiple downstream pathways, including mTORC1, glycogen synthase kinase $3 \beta$ (GSK-3 $\beta$ ) and the FoxO family of transcription factors (Figure 1) [24]. Many of these pathways have been shown to play pivotal roles in normal brain function.

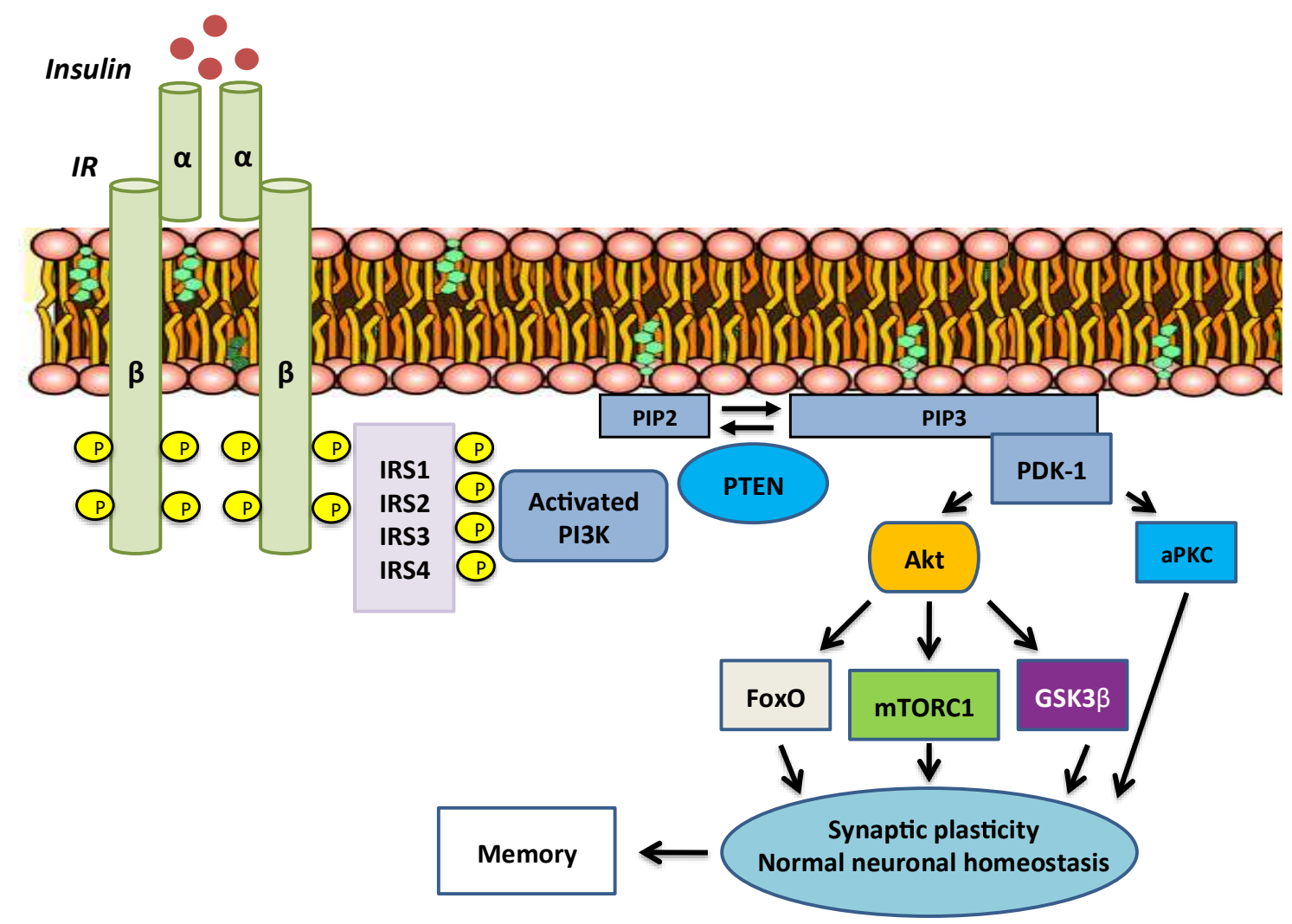

Figure 1. Insulin signalling pathway. After insulin binding to the insulin receptor, autophosphorylation, which is essential for its activation, occurs. Then, the activated insulin receptor phosphorylates IRS proteins. IRSs activate PI3K, which catalyses the addition of a phosphate group to the membrane lipid PIP2, thereby converting it to PIP3. PTEN can convert PIP3 back to PIP2. Membrane-bound PIP3 recruits and activates PDK-1, which phosphorylates and activates Akt and atypical PKCs. Akt mediates most of insulin's metabolic effects and in brain synaptic plasticity, neuronal homeostasis and memory. Abbreviations: IRS (insulin receptor substrate), PI3K (phosphatidylinositol 3 kinase), PIP2 (phosphatidylinositol 4,5-bisphosphate), PIP3 (phosphatidylinositol 3,4,5-trisphosphate), PTEN (phosphatase and tensin homolog), PDK-1 (phosphoinositide-dependent protein kinase-1), PKC (protein kinase c), Akt (protein kinase b), mTORC1 (mammalian target of rapamycin complex 1), GSK3 $\beta$ (glycogen synthase kinase $3 \beta$ ), FoxO (forkhead box O).

\section{T2DM and Neurodegeneration: The Role of Impaired Insulin Signalling, Insulin Resistance and Hyperinsulinemia}

T2DM is a complex, age-related chronic disease and the increasing prevalence is also of great public concern. Currently, more than four hundred million people have diabetes mellitus worldwide and this number is expected to increase dramatically by the next thirty years [25]. T2DM, characterized by cellular insulin resistance and chronic inflammation, causes accelerated aging [26] and leads to premature morbidity and mortality. The effects of T2DM on the brain are now well recognized: it 
is known to be a major risk factor for cognitive decline and dementia. In fact, T2DM increases the long-term risk of dementia by nearly 2 -fold and one in ten cases of dementia in the world population may be attributable to the effects of T2DM [4]. The reciprocal link in the prevalence of these chronic disorders is due to the fact that diabetes and dementia share several important features leading to brain damage, the most important of which are the impaired insulin sensitivity, $\mathrm{A} \beta$ accumulation, tau hyper-phosphorylation, vascular damage and inflammation (Figure 2). The systematic examination of all these connections is not the objective of the present review. Instead we will focus on the role of insulin signalling in the crucial hallmarks of AD-related damage.

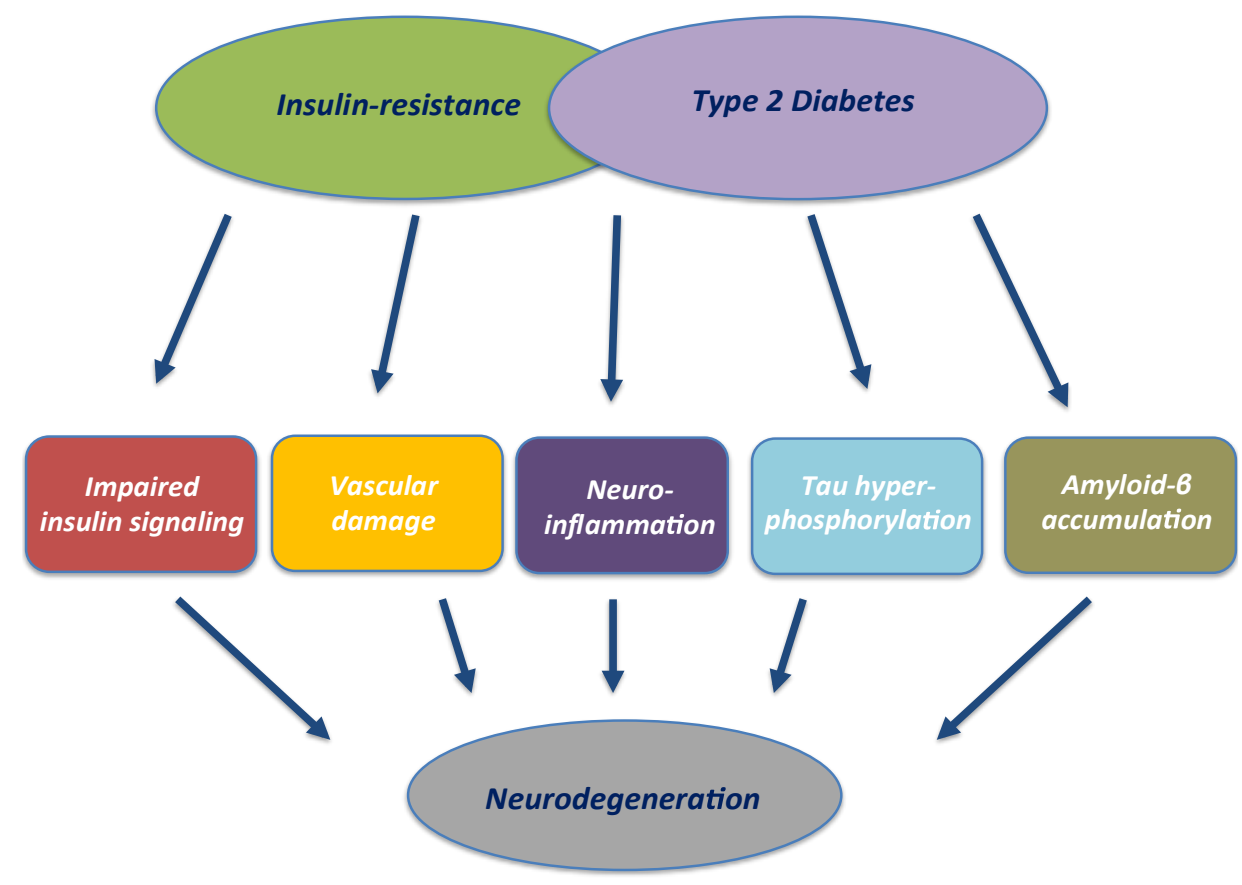

Figure 2. Contribution of T2DM and insulin resistance to neurodegeneration. Metabolic changes resulting from T2DM and insulin resistance can impact on the brain, resulting in synaptic dysfunction and promoting triggers/drivers of neurodegeneration: impaired neuronal insulin signalling, vascular damage, neuroinflammation, tau phosphorylation and $A \beta$ accumulation.

Alzheimer's disease (AD) is a chronic neurodegenerative disease that usually starts slowly and worsens over time. It is the cause of $60-70 \%$ of cases of dementia [27]. The most common early symptom is difficulty in remembering recent events (short-term memory loss). As the disease advances, symptoms can include problems with language, disorientation, mood swings, loss of motivation, not managing self-care and behavioural issues [28]. This progressive neurodegenerative disease is characterized by the accumulation in the brain of extracellular neuritic plaques and fibrils (primarily consisting of aggregated of Amyloid $\beta-\mathrm{A} \beta$-peptides), intracellular neurofibrillary tangles (accumulation of hyper-phosphorylated protein tau-NFTs), microglial infiltration, brain atrophy and widespread synaptic and neuronal loss. Enhanced neuroinflammation is also consistently observed in $\mathrm{AD}[29]$ and evidence suggests that early hyperactivity of pro-inflammatory pathways in the brain precedes the development of plaques and tangles in AD [30].

Several pathophysiological links have been demonstrated between AD and metabolic disorders such as T2DM, obesity and metabolic syndrome [31-33]. In contrast to a small subset of AD cases $(\sim 3 \%)$ attributable to inherited genetic causes, the pathogenesis and aetiology of sporadic, late onset $\mathrm{AD}$ (LOAD) are multifactorial, involving genetic and life-style risk factors [34]. Failure to consider these additional metabolic aspects of AD limits opportunity to fully understand the nature of disease and therapeutically target its underlying basis. 
The recognition of T2DM as a major risk factor for dementia, particularly $\mathrm{AD}$, has driven research to understand the underlying mechanisms linking these two age-related chronic disorders. Metabolic disturbances associated with the diabetic phenotype (i.e., hyperglycaemia, hyperinsulinemia, hypercholesterolemia) are known to be associated with brain atrophy and the pathological features of $\mathrm{AD}$ [3]. Whether insulin resistance is a cause or consequence of $\mathrm{AD}$ is still not clear; however, insulin action has been shown to play a role in several important parts of the progressive pathogenesis of $\mathrm{AD}$ (Figure 2).

Lower brain glucose uptake and impaired glucose metabolism are associated with AD [35]. Moreover, many findings support the concept that insulin-signalling dysregulation may be a key early contributing factor in AD pathogenesis. Several mechanisms can explain the correlation between $\mathrm{AD}$ and insulin signalling defects. In fact, some studies showed that the expression and activation of IR, IGF-1R and IRS-1 proteins is reduced in the brain of AD patients compared to healthy control brains [36]. Moreover, some authors demonstrated that neocortical levels of insulin and binding to insulin receptors are reduced in AD brains [37]. Finally, a lower insulin concentration in the CSF in spite of higher plasma insulin concentration [38], suggests reduced insulin action in the CNS.

\section{Insulin Signalling and Metabolism and $\mathrm{A} \beta$ Deposition}

The amyloid plaques found in the brains of patients with AD are mainly composed of $A \beta$, a peptide derived from a larger molecule that is known as the amyloid precursor protein (APP). APP is normally cleaved within its extracellular domain by the enzyme called " $\alpha$-secretase". Damaging A $\beta$ originate from proteolysis of the APP by the sequential enzymatic actions of beta-site amyloid precursor protein-cleaving enzyme 1 (BACE- 1 ), a $\beta$-secretase and $\gamma$-secretase. An imbalance between production, clearance and aggregation of peptides, causes $A \beta$ to accumulate and this excess may be the initiating factor in AD [39].

Several evidences suggested a link between energy metabolism defects to functional alterations associated with pathogenesis of AD [40]. Inhibition of energy metabolism can alter APP processing and induce amyloidogenic products [41]. The relationship between insulin and $A \beta$ metabolism is recently receiving increasing attention and a direct link between the $\mathrm{A} \beta$ metabolism and insulin pathways has been described in neuronal cell lines [42].

It is known that small oligomers of $\mathrm{A} \beta$ contribute to the synapto-toxicity and downstream events that lead to the neurodegenerative processes in $\mathrm{AD}[43,44]$. As part of these neurodegenerative processes, $A \beta$ oligomers appear to have detrimental effects on insulin signalling by inhibiting auto-phosphorylation of the receptor [45] and to markedly reduce IR levels and activity at the cell surface of the dendrites of hippocampal neurons [46]. IR plays a key role in the important neurological processes including learning and memory and tau phosphorylation. Thus, A $\beta$ oligomer-induced loss of membrane IRs might represent important early mechanism underlying memory impairment and other pathological features of AD.

$\mathrm{A} \beta$ oligomers have also been found to determine aberrant activation of the TNF $\alpha / \mathrm{JNK}$ and IRS-1 inhibition in both in vitro and in vivo models [21,47]. Furthermore, A $\beta$ oligomers also have effects on signalling downstream from IRS- 1 and PI3K, where they can activate serine phosphorylation of Akt and promote inflammatory processes [48]. On the other hand, insulin resistance is known to accelerate $A \beta$ production promoting its accumulation. When insulin resistance is induced in transgenic AD mice or in diabetic obese mice through feeding a high fat diet, the mice exhibit increased brain $A \beta$ levels and increases in levels of the key enzymes that generate $A \beta$ (like $\gamma$-secretase) [49]. Finally, insulin and $A \beta$ are both substrates of insulin-degrading enzyme and it has been suggested that hyperinsulinemia inhibits the degradation of $A \beta$ by competitively blocking insulin-degrading enzyme [50]. 


\section{Impairment of Insulin Signalling and Tau Hyper-Phosphorylation}

Deficiencies in insulin signalling could also exacerbate neurodegeneration by enhancing the phosphorylation of tau protein. Tau is a neuronal microtubule-associated protein found in axons. It plays an important role in assembly and stability of microtubules as well as in vesicle transport in neurons. In $\mathrm{AD}$, the hyper-phosphorylation of the microtubule-associated protein tau to form NFTs is an important pathological hallmark and smaller aggregates of hyper-phosphorylated tau are considered to contribute to neuronal dysfunction and degeneration [51]. It has been shown that insulin and IGF-1 regulate tau phosphorylation through the inhibition of GSK-3 $\beta$ in cultural neurons [52]. GSK-3 $\beta$ represents a key kinase that phosphorylates tau. Deficiencies or impairments in brain insulin signalling lead to a reduction in Akt activity resulting in an increase in GSK-3 $\beta$ activity. This phenomenon produces the hyper-phosphorylation of tau and, therefore, the formation of tau fibrils [53]. Moreover, peripheral hyperinsulinemia promotes tau phosphorylation in vivo [54]. It has been demonstrated that when IGF-1 and IRS-2 gene are deleted, tau phosphorylation is dramatically increased in IGF-1 and IRS-2 knockout mice [17,55]. Indeed, IGF-1 genetic deletion specifically increases tau phosphorylation at two specific GSK-3 $\beta$ targeted sites [55]. These results suggest that insulin and IGF-1 signalling normally prevents tau hyperphosphorylation in the brain. Given that T2DM is characterized by insulin resistance, hyperinsulinemia and impaired insulin signalling, it is not surprising that an increased GSK-3 $\beta$ activity in T2DM might lead to an elevation of A $\beta$ production [56] and increased tau phosphorylation [57].

Insulin can also regulate tau expression and reduced insulin signalling can result in impaired tau gene expression [48] leading to reduced levels of normal soluble tau whilst hyper-phosphorylated tau accumulates, exacerbating neuronal cytoskeletal collapse, neurite retraction and impairments in synapse formation. Moreover, it has been demonstrated that the AD-associated reduction in tau mRNA expression is correlated to the impaired insulin and IGF-1 signalling observed in the same AD samples [58] demonstrating the strong connection between the two mechanisms.

\section{Insulin Resistance, Brain Vasculopathy and Neuroinflammation}

Neurodegenerative disorders and T2DM are both characterized by vascular damage, reduced cerebral flow and aberrant inflammatory response [59].

It has been demonstrated that AD patients have a decreased regional cerebral blood flow that could result in decrease brain supply of oxygen, glucose and nutrients [59,60]. This phenomenon is partially mediated by an impaired insulin transduction pathway. Insulin signalling, in fact, is involved in the regulation of vasodilation and vasoconstriction [61]. IR activation mediates vasodilation through $\mathrm{PI} 3 \mathrm{~K} /$ Akt pathway. It stimulates endothelial nitric oxide synthase (eNOS) resulting in the production of nitric oxide (NO) and vascular relaxation [61]. In insulin resistant state, there is a specific impairment in the vasodilatory PI3K pathway, resulting in decreased NO production and, therefore, leading to vasoconstriction. The resultant decrease in nutrient availability to the brain determines an increase of oxidative stress and reactive oxygen species (ROS) production and, consequently, an increased inflammatory response. Released pro-inflammatory cytokines and macrophage recruitment instigates the onset of atherosclerosis, ultimately leading to macrovascular complications [59].

It is well recognized that inflammatory processes form a major part of the pathogenesis of T2DM as well as neurodegenerative diseases. Indeed, there is mounting evidence that such induced chronic inflammation is an important early stage of AD pathogenesis [62,63].

Hyperinsulinemia has been shown to promote inflammatory responses in the CNS [64]. Increased peripheral insulin levels have been found to lead to increased cerebral levels of pro-inflammatory cytokines such as interleukin-1 $\beta$ (IL-1 $\beta$ ), interleukin-6 (IL-6) and tumour necrosis factor- $\alpha$ (TNF- $\alpha)$, all of which have been reported to be elevated in AD and have been located in amyloid plaques and their related glial cells in AD patients [65].

In peripheral insulin resistance, the production of inflammatory cytokines and activation of inflammatory stress signalling, can lead to serine phosphorylation of IRS-1 by kinases, inhibitor of 
kappa B kinase (IKK), c-Jun N-terminal Kinase (JNK) and extracellular signal-regulated kinase 2 (ERK2), which in turn interfere with IR-mediated signalling, blocking the intracellular actions of insulin [66]. A similar mechanism has been suggested to occur in the brain, where A $\beta$ oligomers can activate microglia, resulting in the secretion of pro-inflammatory cytokines, which bind to their respective receptors, activating one or more of the IRS-1 serine kinases [47] and in turn phosphorylating IRS at multiple sites. Elevated levels of vascular pro-inflammatory cytokines, observed in both T2DM and $\mathrm{AD}$, can also impact on brain insulin signalling. When cerebral vascular tissue is damaged, cytokines can, in fact, cross the BBB and can activate phosphorylation of IRS-1 [67,68].

Vascular inflammation can also be mediated by the receptor for advanced glycation end products (RAGE). RAGE is expressed in neuronal cells, microglia astrocytes and in brain endothelial cells and levels are increased in both AD and T2DM. Increased RAGE levels have been proposed as a possible mechanism for vascular dysfunction in both T2DM and AD [69] and the interactions between disturbed cerebral glucose metabolism, oxidative stress and the accumulation of AGE's are important in the vicious cycle that contributes to AD progression [70]. RAGE is an avenue for receptor mediated transport of $\mathrm{A} \beta$ across the BBB from the periphery to the brain [71], inducing cerebrovascular dysfunction resulting in neurovascular stress, production of TNF- $\alpha$ and IL-6, contributing to synapto-toxicity and neurodegeneration [69].

\section{Therapeutic Implications}

As T2DM shares several characteristics with neurodegenerative disorders, as previously discussed, it has been suggested that several drugs used in the treatment of T2DM could have potential benefits in AD (Table 1).

Table 1. Effects of antidiabetic drugs on central nervous system (CNS).

\begin{tabular}{|c|c|c|}
\hline Drugs & Effects on CNS & Ref. \\
\hline \multirow[t]{9}{*}{ Metformin } & $\begin{array}{l}\text { Restores mitochondria, attenuates AGEs effects through the activation of AMPK in } \\
\text { human neural stem cells }\end{array}$ & {$[72,73]$} \\
\hline & $\begin{array}{l}\text { Re-sensitizes impaired insulin signalling and reduces phosphorylation of tau, } \\
\text { in neuronal cell lines }\end{array}$ & [74] \\
\hline & $\begin{array}{l}\text { Induces protein phosphatase } 2 \mathrm{~A} \text { and reduces tau phosphorylation in murine neurons } \\
\text { of Tau transgenic mouse }\end{array}$ & [75] \\
\hline & Attenuates cognitive impairment in obese leptin resistant mice & [76] \\
\hline & Increases the generation of amyloid beta protein, in human cell models (negative effect) & [77] \\
\hline & Decreases the risk of cognitive decline in diabetic patients & [78] \\
\hline & Improves depressive and cognitive performance in depressed patients & [79] \\
\hline & $\begin{array}{l}\text { Protective effect on domain of verbal learning, working memory and executive } \\
\text { function }\end{array}$ & [80] \\
\hline & $\begin{array}{l}\text { Increases the risk of cognitive impairment in studies conducted on AD patients } \\
\text { (negative effect) }\end{array}$ & [81] \\
\hline \multirow[t]{4}{*}{ Sulfonylureas } & $\begin{array}{l}\text { Glimepiride protects neurons against beta amyloid induced synapse degeneration, } \\
\text { in vitro }\end{array}$ & [82] \\
\hline & Gliclazide exerts antioxidant effect in the brain, in diabetic rats & [83] \\
\hline & Glibenclamide decreases depression and anxiety, in a rat model of AD & [84] \\
\hline & In combination with metformin, reduce the risk of dementia, in diabetic patients & [85] \\
\hline \multirow[t]{6}{*}{ Glitazones } & Neuroprotective effects in $\mathrm{AD}$ related to inhibition of inflammation and $\mathrm{A} \beta$ deposition & [86] \\
\hline & Pioglitazone reduces AD-related pathologies suppressing glial activation, in mice & [87] \\
\hline & $\begin{array}{l}\text { Pioglitazone enhances Akt signalling and tau hyperphosphorylation, in mouse model } \\
\text { of AD }\end{array}$ & [88] \\
\hline & $\begin{array}{l}\text { In combination with leptin, pioglitazone reduces brain amyloid levels, in mouse model } \\
\text { of } \mathrm{AD}\end{array}$ & [89] \\
\hline & Pioglitazone improves cognition and regional cerebral blood flow of T2DM patients & [90] \\
\hline & $\begin{array}{l}\text { Pioglitazone may provide an improvement in early stage and in mild to moderate AD } \\
\text { in humans }\end{array}$ & [91] \\
\hline
\end{tabular}


Table 1. Cont.

\begin{tabular}{|c|c|c|}
\hline Drugs & Effects on CNS & Ref. \\
\hline \multirow[t]{4}{*}{ GLP-1 RA } & $\begin{array}{l}\text { Reduce apoptosis and oxidative stress; ameliorate synaptic plasticity in AD } \\
\text { mouse model }\end{array}$ & [92] \\
\hline & Influence cellular pathways of neuronal protection and mitochondrial function & [93] \\
\hline & $\begin{array}{l}\text { Reduce tau phosphorylation, prevent synaptic loss, diminish } \mathrm{A} \beta \text { deposition in } \mathrm{AD} \\
\text { mouse model }\end{array}$ & {$[94,95]$} \\
\hline & $\begin{array}{l}\text { Prevent the decline of brain glucose metabolism in } \mathrm{AD} \text { patients with } \\
\text { long-standing disease }\end{array}$ & [96] \\
\hline \multirow[t]{3}{*}{ DPP4-i } & $\begin{array}{l}\text { Decrease tau phosphorylation, amyloid load and the cognitive deficits with memory } \\
\text { improvement }\end{array}$ & {$[97,98]$} \\
\hline & $\begin{array}{l}\text { Improve incretin levels, reduce A } \beta \text { deposition, tau phosphorylation, GSK-3 } \beta \\
\text { activation and ROS }\end{array}$ & [99] \\
\hline & $\begin{array}{l}\text { Improve glucose control and prevent worsening of cognitive function, in older } \\
\text { patients with T2DM }\end{array}$ & [100] \\
\hline \multirow[t]{3}{*}{ Insulin } & Attenuates cognitive decline and enhances memory in adults with $\mathrm{AD}$ & {$[101,102]$} \\
\hline & $\begin{array}{l}\text { In vitro inhibits apoptosis; in vivo regulates tau phosphorylation, } A \beta \text { metabolism } \\
\text { and clearance }\end{array}$ & [103] \\
\hline & $\begin{array}{l}\text { Improves memory, mood, cerebral glucose metabolism; preserves brain volume in } \\
\text { AD patients }\end{array}$ & [104] \\
\hline
\end{tabular}

\section{Metformin}

Metformin is a biguanide that reduces insulin-mediated hepatic glucose production, increases insulin sensitivity and represents first-line treatment for T2DM. It rapidly crosses the BBB, distributes into several brain regions [105] and, by the activation of the AMPK pathway, seems to have a neuroprotective effect on human neural stem cells, restoring mitochondrial functions and attenuating AGEs effects [72,73].

Data on effects of metformin in neurodegenerative disorders are contrasting. In vitro studies reported the ability of metformin to reduce phosphorylation of tau, in neuronal cell lines [74] or in murine primary neurons from wild type and human tau transgenic mice [75]. In vivo studies have shown that in obese leptin resistant mice, metformin attenuated cognitive impairment and AD-like pathology [76]. In contrast, a study on cell culture showed that metformin increases the generation of amyloid beta protein [77].

In humans, observational studies show reduction in mild cognitive impairment (MCI) [78] and dementia $[85,106]$ among participants with diabetes taking metformin when compared with no medication or other glucose-lowering agents. Long-term treatment with metformin seems to decrease the risk of cognitive decline in diabetic patients [78] and improve depressive and cognitive performance, changing the glucose metabolism, in depressed patients [79]. A recent pilot clinical trial in patients with $\mathrm{MCI}$, randomly assigned to receive metformin or placebo for 12 months, showed that metformin improved cognition in individuals without diabetes [107].

A clinical study examining the effect of different diabetes treatments on cognitive function showed that diabetic patients who used metformin alone had a better cognitive function for the domain of verbal learning, working memory and executive function compared to participants on other forms of diabetic treatment [80].

On the other hand, an increased risk of cognitive impairment and developing AD was demonstrated with the use of metformin in a study conducted on AD patients [81]. This phenomenon was partially mediated by the metformin-induced vitamin B12 deficiency; in fact, it became weaker after adjusting for serum vitamin B12 levels. Nevertheless, the results of an analysis of cognitive function, measured 8-10 years after therapy with metformin in the Diabetes Prevention Program Outcomes Study (DPPOS) [108], did not show any negative impact from long-term metformin use.

Upcoming randomized clinical trials will evaluate whether metformin can prevent cognitive decline or improve cognitive functions in humans [109]. 


\section{Sulfonylureas}

Sulfonylureas are antidiabetic drugs that stimulate insulin release by blocking ATP sensitive potassium channels on pancreatic beta cells. In vitro, glimepiride protects neurons against betaamyloid-induced synapse degeneration [82]. In streptozotocin-induced diabetic rats, gliclazide was able to exert an antioxidant effect in the brain [83]. Also, glibenclamide decreases depression and anxiety in a rat model of AD [84].

An 8 years clinical prospective study conducted on diabetic patients showed that the combination of sulfonylureas and metformin reduced the risk of dementia [85], however, another case control study demonstrated that long term use of sulfonylureas does not modify risk of dementia [110].

More extensive studies are needed to verify the potential therapeutic role of this class of drugs.

\section{Thiazolidinediones (Glitazones)}

Thiazolidinediones (TZDs), pioglitazone and rosiglitazone, are potent and selective receptor agonist of peroxisome proliferator-activated receptor- $\gamma$ (PPAR- $\gamma$ ) nuclear receptors that improve insulin sensitivity in muscle, adipose and hepatic tissue; reducing systemic insulin resistance. TZDs may have a role on improvement of neuronal function and memory formation. These drugs showed a neuroprotective effects in AD related to inhibition of inflammatory gene expression and alteration of amyloid beta generation and deposition [86].

Pioglitazone, the only TZD actually available in commerce, is able to enter the brain, suppress glial activation and reduces AD-related pathologies [87].

In mouse models of $\mathrm{AD}$, pioglitazone administered for 4 months enhances Akt signalling, attenuates spatial learning impairment and tau hyperphosphorylation [88]. Moreover, used in combination therapy with leptin reduces spatial memory deficits and brain amyloid levels [89].

In human, a pilot study showed improvement of cognition and regional cerebral blood flow in the parietal lobe of subjects with T2DM treated with pioglitazone for 6 months [90]. However, an 18-months trial in nondiabetic patients with $\mathrm{AD}$, designed to evaluate the safety of pioglitazone, showed as secondary outcomes no treatment effects in cognition [111].

A meta-analysis on effect of PPAR gamma agonist in AD patients demonstrated that only pioglitazone may provide an improvement in the early stages and in mild-to-moderate AD [91,112].

A phase 3 clinical trial on the efficacy of pioglitazone in patients with mild cognitive impairment is ongoing, also using an algorithm to evaluate genetic-based biomarkers for preclinical diagnosis such as APOE status and genotypes. (Clinical trial identifier: NCT01931566). Data will be available in 2019.

\section{Glucagon-Like Peptide-1 (GLP-1) Receptor Agonists}

Another class of antidiabetic drugs is that of the GLP-1 receptor agonists. GLP-1 is an incretin peptide secreted by the intestine that enhance glucose-dependent insulin secretion and inhibits glucagon secretion for maintaining glucose homeostasis. GLP-1 also has trophic properties as stimulation of $\beta$-cell neogenesis, growth and differentiation, inhibition of $\beta$-cell apoptosis and enhancement of cell survival $[113,114]$.

GLP-1 and most of analogues cross over the BBB and GLP-1 receptor is expressed throughout the brain, in the frontal cortex, hypothalamus, thalamus, hippocampus, cerebellum and substantia nigra [115]. GLP-1 has a neuroprotective role: in the brain of AD mouse models, it seems to reduce apoptosis, protect neurons from oxidative stress and synapses from the harmful effects of reduced synaptic plasticity in the hippocampus induced by beta-amyloid [92]. Native GLP-1 has short half-life because is easily degraded by dipeptidyl peptidase-4 (DPP-4). Several GLP-1 analogues, more stable and more slowly degraded than GLP-1 native, have been developed; among these, exenatide, liraglutide and lixisenatide cross the BBB and, independently from their effects on glucose control, influence cellular pathways of neuronal protection, mitochondrial function, apoptosis and oxidative stress [93]. For their neuroprotective effects, GLP-1 analogues have been investigated as potential treatment of $\mathrm{AD}$ and other neurodegenerative disorders. In studies on $\mathrm{AD}$ mouse models, 
GLP-1 analogues reduced neuronal tau hyperphosphorylation, prevented synaptic loss, improved motor function, enhanced synaptic plasticity, attenuated memory and learning deficits and diminished beta amyloid plaque load in the brain [94,95]. The neuroprotective effects of liraglutide seem to be mediated through the PI3K-Akt signalling pathway [116] while those of lixisenatide were attributed to induced Akt and MEK signalling pathways [117].

A pilot clinical trial on humans showed that 6 months of liraglutide treatment in AD patients with long-standing disease prevents the decline of brain glucose metabolism expected as a sign of disease progression; in this study, however, no differences were found in beta- amyloid deposition or in cognition [96]. Other phase II trials evaluating GLP-1 analogues in patients with AD are ongoing.

Certainly, GLP-1 analogues have the advantage of not affecting blood sugar levels in nondiabetic people and so may represent a potential safe treatment for $\mathrm{AD}$ or other neurodegenerative conditions also in non-diabetic patients.

\section{Dipeptidyl Peptidase-4 Inhibitors (DPP-4i)}

DPP-4i (gliptins) are antidiabetic drugs that, inhibiting DPP-4, proteolytic enzymes responsible for degradation of GLP-1, extend its plasma half-life, stabilizing its level and inducing a functional enhancement of its antidiabetic effect. DPP-4 inhibitors have shown neuroprotective effects that could be partially mediated through the effects of GLP-1 in the brain.

In AD animal models, DPP-4i inhibitors treatment (saxagliptin, vildagliptin, sitagliptin) decreases tau phosphorylation, amyloid load and inflammatory markers but also reverses the cognitive deficits with memory improvement $[97,98]$.

In human neuronal cells, linagliptin protects against beta-amyloid toxicity and tau hyperphosphorylation, preventing the activation of GSK3 $\beta$ and attenuates intracellular ROS production by stimulating 5'AMP-activated protein kinase (AMPK)-Sirt1 signalling [99]. All these effects contribute to the amelioration of cognitive deficits. Effects of DPP-4i have been investigated in clinical studies. In older patients affected by T2DM and mild cognitive impairment, DPP-4 inhibitor treatment improves glucose control and prevents worsening of cognitive functions [100]. Also, a prospective clinical study evaluating 6-months sitagliptin treatment in elderly diabetic patients reported improvement of cognitive function [118].

\section{Insulin}

Insulin exerts several effects in the brain regarding cognition, learning, memory and synaptic plasticity, probably involving the complex insulin/IR signalling pathway. Insulin administration attenuates cognitive decline [101,119] and enhances memory in adults with AD [102]. However, insulin systemic administration is associated with reduced penetration in the brain and higher risk of hypoglycaemia. For these reasons, in several clinical studies, intranasal administration of insulin has been tested. After intranasal administration, insulin bypasses the BBB and reaches biologically significant concentrations in the brain [102]. In vitro, insulin inhibits neuronal apoptosis via activation of protein kinase B and in vivo it regulates tau phosphorylation, beta-amyloid precursor protein metabolism and beta-amyloid clearance [103].

Intranasal insulin administration improves memory and enhance mood in healthy adults but also in patients with mild cognitive impairment and late onset $\mathrm{AD}$ in which improves cerebral glucose metabolism and preserves volume of brain regions affected by AD pathology [104]. Therapeutic insulin effects on CNS are dose dependent and modulated by APOE genotype, a strong genetic predictor for $\mathrm{AD}[102]$.

\section{Conclusions}

It is now recognized that insulin can exert an important effect on brain function. Alterations in insulin metabolism and signalling can contribute to the development of neurodegenerative disorders, such as $\mathrm{AD}$, influencing the regulation of their neuro-pathological hallmarks. 
A number of in vivo and in vitro studies confirm the close relationship between T2DM and neurodegeneration and suggest a potential therapeutic role of several anti-diabetics in prevention or treatment of disorders like AD. However, underlying common mechanisms between T2DM and neurodegenerative diseases, as well as determinants of antidiabetic effects on neurodegeneration are not completely known and further studies are needed to clarify these pathophysiological links and the related therapeutic implications.

Author Contributions: Conceptualization, A.T. and L.F.; Resources, F.V. and M.P.; Original Draft Preparation, A.T., F.V., M.P., L.F.; Review and Editing, A.T., F.V., M.P., L.F.; Supervision, L.F.

Funding: This research received no external funding.

Acknowledgments: Miriam Parisi is a recipient of a post-doctoral fellowship founded by the Department of Clinical and Experimental Medicine, University of Catania, Catania (Italy).

Conflicts of Interest: The authors declare no conflict of interest.

\section{References}

1. Chiu, S.L.; Chen, C.M.; Cline, H.T. Insulin receptor signaling regulates synapse number, dendritic plasticity, and circuit function in vivo. Neuron 2008, 58, 708-719. [CrossRef] [PubMed]

2. Apostolatos, A.; Song, S.; Acosta, S.; Peart, M.; Watson, J.E.; Bickford, P.; Cooper, D.R.; Patel, N.A. Insulin promotes neuronal survival via the alternatively spliced protein kinase CdeltaII isoform. J. Biol. Chem. 2012, 287, 9299-9310. [CrossRef] [PubMed]

3. Kleinridders, A.; Ferris, H.A.; Cai, W.; Kahn, C.R. Insulin action in brain regulates systemic metabolism and brain function. Diabetes 2014, 63, 2232-2243. [CrossRef] [PubMed]

4. Biessels, G.J.; Strachan, M.W.; Visseren, F.L.; Kappelle, L.J.; Whitmer, R.A. Dementia and cognitive decline in type 2 diabetes and prediabetic stages: Towards targeted interventions. Lancet Diabetes Endocrinol. 2014, 2, 246-255. [CrossRef]

5. Vigneri, R.; Goldfine, I.D.; Frittitta, L. Insulin, insulin receptors, and cancer. J. Endocrinol. Investig. 2016, 39, 1365-1376. [CrossRef] [PubMed]

6. Derakhshan, F.; Toth, C. Insulin and the brain. Curr. Diabetes Rev. 2013, 9, 102-116. [PubMed]

7. Woods, S.C.; Seeley, R.J.; Baskin, D.G.; Schwartz, M.W. Insulin and the blood-brain barrier. Curr. Pharm. Des. 2003, 9, 795-800. [CrossRef] [PubMed]

8. Martins, J.P.; Alves, C.J.; Neto, E.; Lamghari, M. Communication from the periphery to the hypothalamus through the blood-brain barrier: An in vitro platform. Int. J. Pharm. 2016, 499, 119-130. [CrossRef] [PubMed]

9. Devaskar, S.U.; Giddings, S.J.; Rajakumar, P.A.; Carnaghi, L.R.; Menon, R.K.; Zahm, D.S. Insulin gene expression and insulin synthesis in mammalian neuronal cells. J. Biol. Chem. 1994, 269, 8445-8454. [PubMed]

10. Pomytkin, I.; Costa-Nunes, J.P.; Kasatkin, V.; Veniaminova, E.; Demchenko, A.; Lyundup, A.; Lesch, K.P.; Ponomarev, E.D.; Strekalova, T. Insulin receptor in the brain: Mechanisms of activation and the role in the CNS pathology and treatment. CNS Neurosci. Ther. 2018. [CrossRef] [PubMed]

11. Belfiore, A.; Malaguarnera, R.; Vella, V.; Lawrence, M.C.; Sciacca, L.; Frasca, F.; Morrione, A.; Vigneri, R. Insulin Receptor Isoforms in Physiology and Disease: An Updated View. Endocr. Rev. 2017, 38, 379-431. [CrossRef] [PubMed]

12. Belfiore, A.; Frasca, F.; Pandini, G.; Sciacca, L.; Vigneri, R. Insulin receptor isoforms and insulin receptor/insulin-like growth factor receptor hybrids in physiology and disease. Endocr. Rev. 2009, 30, 586-623. [CrossRef] [PubMed]

13. Holscher, C. New drug treatments show neuroprotective effects in Alzheimer's and Parkinson's diseases. Neural Regen. Res. 2014, 9, 1870-1873. [CrossRef] [PubMed]

14. Akintola, A.A.; van Heemst, D. Insulin, aging, and the brain: Mechanisms and implications. Front. Endocrinol. 2015, 6, 13. [CrossRef] [PubMed]

15. Numan, S.; Russell, D.S. Discrete expression of insulin receptor substrate-4 mRNA in adult rat brain. Brain Res. Mol. Brain Res. 1999, 72, 97-102. [CrossRef]

16. Araki, E.; Lipes, M.A.; Patti, M.E.; Bruning, J.C.; Haag, B., 3rd; Johnson, R.S.; Kahn, C.R. Alternative pathway of insulin signalling in mice with targeted disruption of the IRS-1 gene. Nature 1994, 372, 186-190. [CrossRef] [PubMed] 
17. Schubert, M.; Brazil, D.P.; Burks, D.J.; Kushner, J.A.; Ye, J.; Flint, C.L.; Farhang-Fallah, J.; Dikkes, P.; Warot, X.M.; Rio, C.; et al. Insulin receptor substrate-2 deficiency impairs brain growth and promotes tau phosphorylation. J. Neurosci. Off. J. Soci. Neurosci. 2003, 23, 7084-7092. [CrossRef]

18. Taguchi, A.; Wartschow, L.M.; White, M.F. Brain IRS2 signaling coordinates life span and nutrient homeostasis. Science 2007, 317, 369-372. [CrossRef] [PubMed]

19. Sadagurski, M.; Dong, X.C.; Myers, M.G., Jr.; White, M.F. Irs2 and Irs4 synergize in non-LepRb neurons to control energy balance and glucose homeostasis. Mol. Metab. 2014, 3, 55-63. [CrossRef] [PubMed]

20. Bruning, J.C.; Gautam, D.; Burks, D.J.; Gillette, J.; Schubert, M.; Orban, P.C.; Klein, R.; Krone, W.; Muller-Wieland, D.; Kahn, C.R. Role of brain insulin receptor in control of body weight and reproduction. Science 2000, 289, 2122-2125. [CrossRef] [PubMed]

21. Bomfim, T.R.; Forny-Germano, L.; Sathler, L.B.; Brito-Moreira, J.; Houzel, J.C.; Decker, H.; Silverman, M.A.; Kazi, H.; Melo, H.M.; McClean, P.L.; et al. An anti-diabetes agent protects the mouse brain from defective insulin signaling caused by Alzheimer's disease-associated Abeta oligomers. J. Clin. Investig. 2012, 122, 1339-1353. [CrossRef] [PubMed]

22. Talbot, K.; Wang, H.Y.; Kazi, H.; Han, L.Y.; Bakshi, K.P.; Stucky, A.; Fuino, R.L.; Kawaguchi, K.R.; Samoyedny, A.J.; Wilson, R.S.; et al. Demonstrated brain insulin resistance in Alzheimer's disease patients is associated with IGF-1 resistance, IRS-1 dysregulation, and cognitive decline. J. Clin. Investig. 2012, 122, 1316-1338. [CrossRef] [PubMed]

23. Denver, P.; English, A.; McClean, P.L. Inflammation, insulin signaling and cognitive function in aged APP/PS1 mice. Brain Behav. Immun. 2018, 70, 423-434. [CrossRef] [PubMed]

24. Boucher, J.; Kleinridders, A.; Kahn, C.R. Insulin receptor signaling in normal and insulin-resistant states. Cold Spring Harb. Perspect. Biol. 2014, 6. [CrossRef] [PubMed]

25. Cho, N.H.; Shaw, J.E.; Karuranga, S.; Huang, Y.; da Rocha Fernandes, J.D.; Ohlrogge, A.W.; Malanda, B. IDF Diabetes Atlas: Global estimates of diabetes prevalence for 2017 and projections for 2045. Diabetes Res. Clin. Pract. 2018, 138, 271-281. [CrossRef] [PubMed]

26. Pugazhenthi, S.; Qin, L.; Reddy, P.H. Common neurodegenerative pathways in obesity, diabetes, and Alzheimer's disease. Biochim. Biophys. Acta Mol. Basis Dis. 2017, 1863, 1037-1045. [CrossRef] [PubMed]

27. Reitz, C.; Mayeux, R. Alzheimer disease: Epidemiology, diagnostic criteria, risk factors and biomarkers. Biochem. Pharmacol. 2014, 88, 640-651. [CrossRef] [PubMed]

28. Anor, C.J.; O'Connor, S.; Saund, A.; Tang-Wai, D.F.; Keren, R.; Tartaglia, M.C. Neuropsychiatric Symptoms in Alzheimer Disease, Vascular Dementia, and Mixed Dementia. Neuro-Degener. Dis. 2017, 17, 127-134. [CrossRef] [PubMed]

29. McGeer, P.L.; McGeer, E.G. The amyloid cascade-inflammatory hypothesis of Alzheimer disease: Implications for therapy. Acta Neuropathol. 2013, 126, 479-497. [CrossRef] [PubMed]

30. Wright, A.L.; Zinn, R.; Hohensinn, B.; Konen, L.M.; Beynon, S.B.; Tan, R.P.; Clark, I.A.; Abdipranoto, A.; Vissel, B. Neuroinflammation and neuronal loss precede Abeta plaque deposition in the hAPP-J20 mouse model of Alzheimer's disease. PLoS ONE 2013, 8, e59586. [CrossRef] [PubMed]

31. Li, J.; Cesari, M.; Liu, F.; Dong, B.; Vellas, B. Effects of Diabetes Mellitus on Cognitive Decline in Patients with Alzheimer Disease: A Systematic Review. Can. J. Diabetes 2017, 41, 114-119. [CrossRef] [PubMed]

32. Sripetchwandee, J.; Chattipakorn, N.; Chattipakorn, S.C. Links Between Obesity-Induced Brain Insulin Resistance, Brain Mitochondrial Dysfunction, and Dementia. Front. Endocrinol. 2018, 9, 496. [CrossRef] [PubMed]

33. Diaz, A.; Escobedo, C.; Trevino, S.; Chavez, R.; Lopez-Lopez, G.; Moran, C.; Guevara, J.; Venegas, B.; Munoz-Arenas, G. Metabolic Syndrome Exacerbates the Recognition Memory Impairment and Oxidative-Inflammatory Response in Rats with an Intrahippocampal Injection of Amyloid Beta 1-42. Oxidative Med. Cell. Longev. 2018, 2018, 1358057. [CrossRef] [PubMed]

34. Pierce, A.L.; Bullain, S.S.; Kawas, C.H. Late-Onset Alzheimer Disease. Neurol. Clin. 2017, 35, $283-293$. [CrossRef] [PubMed]

35. Yin, F.; Sancheti, H.; Patil, I.; Cadenas, E. Energy metabolism and inflammation in brain aging and Alzheimer's disease. Free Rad. Biol. Med. 2016, 100, 108-122. [CrossRef] [PubMed]

36. Denver, P.; McClean, P.L. Distinguishing normal brain aging from the development of Alzheimer's disease: Inflammation, insulin signaling and cognition. Neural Regen. Res. 2018, 13, 1719-1730. [CrossRef] [PubMed] 
37. Frolich, L.; Blum-Degen, D.; Bernstein, H.G.; Engelsberger, S.; Humrich, J.; Laufer, S.; Muschner, D.; Thalheimer, A.; Turk, A.; Hoyer, S.; et al. Brain insulin and insulin receptors in aging and sporadic Alzheimer's disease. J. Neural Trans. 1998, 105, 423-438. [CrossRef] [PubMed]

38. Ratzmann, K.P.; Hampel, R. Glucose and insulin concentration patterns in cerebrospinal fluid following intravenous glucose injection in humans. Endokrinologie 1980, 76, 185-188. [PubMed]

39. Querfurth, H.W.; LaFerla, F.M. Alzheimer's disease. N. Engl. J. Med. 2010, 362, 329-344. [CrossRef] [PubMed]

40. De la Monte, S.M. Insulin Resistance and Neurodegeneration: Progress Towards the Development of New Therapeutics for Alzheimer's Disease. Drugs 2017, 77, 47-65. [CrossRef] [PubMed]

41. Gabuzda, D.; Busciglio, J.; Chen, L.B.; Matsudaira, P.; Yankner, B.A. Inhibition of energy metabolism alters the processing of amyloid precursor protein and induces a potentially amyloidogenic derivative. J. Biol. Chem. 1994, 269, 13623-13628. [PubMed]

42. Gasparini, L.; Gouras, G.K.; Wang, R.; Gross, R.S.; Beal, M.F.; Greengard, P.; Xu, H. Stimulation of beta-amyloid precursor protein trafficking by insulin reduces intraneuronal beta-amyloid and requires mitogen-activated protein kinase signaling. J. Neurosci. Off. J. Soci. Neurosci. 2001, 21, 2561-2570. [CrossRef]

43. Nisbet, R.M.; Polanco, J.C.; Ittner, L.M.; Gotz, J. Tau aggregation and its interplay with amyloid-beta. Acta Neuropathol. 2015, 129, 207-220. [CrossRef] [PubMed]

44. Zimbone, S.; Monaco, I.; Giani, F.; Pandini, G.; Copani, A.G.; Giuffrida, M.L.; Rizzarelli, E. Amyloid Beta monomers regulate cyclic adenosine monophosphate response element binding protein functions by activating type-1 insulin-like growth factor receptors in neuronal cells. Aging Cell 2018, 17. [CrossRef] [PubMed]

45. Ling, X.; Martins, R.N.; Racchi, M.; Craft, S.; Helmerhorst, E. Amyloid beta antagonizes insulin promoted secretion of the amyloid beta protein precursor. J. Alzheimer's Dis. JAD 2002, 4, 369-374. [CrossRef]

46. Zhao, W.Q.; De Felice, F.G.; Fernandez, S.; Chen, H.; Lambert, M.P.; Quon, M.J.; Krafft, G.A.; Klein, W.L. Amyloid beta oligomers induce impairment of neuronal insulin receptors. FASEB J. Off. Publ. Fed. Am. Soc. Exp. Biol. 2008, 22, 246-260. [CrossRef] [PubMed]

47. Ma, Q.L.; Yang, F.; Rosario, E.R.; Ubeda, O.J.; Beech, W.; Gant, D.J.; Chen, P.P.; Hudspeth, B.; Chen, C.; Zhao, Y.; et al. Beta-amyloid oligomers induce phosphorylation of tau and inactivation of insulin receptor substrate via c-Jun N-terminal kinase signaling: Suppression by omega-3 fatty acids and curcumin. J. Neurosci. Off. J. Soci. Neurosci. 2009, 29, 9078-9089. [CrossRef] [PubMed]

48. Schubert, M.; Gautam, D.; Surjo, D.; Ueki, K.; Baudler, S.; Schubert, D.; Kondo, T.; Alber, J.; Galldiks, N.; Kustermann, E.; et al. Role for neuronal insulin resistance in neurodegenerative diseases. Proc. Natl. Acad. Sci. USA 2004, 101, 3100-3105. [CrossRef] [PubMed]

49. Vandal, M.; White, P.J.; Tremblay, C.; St-Amour, I.; Chevrier, G.; Emond, V.; Lefrancois, D.; Virgili, J.; Planel, E.; Giguere, Y.; et al. Insulin reverses the high-fat diet-induced increase in brain Abeta and improves memory in an animal model of Alzheimer disease. Diabetes 2014, 63, 4291-4301. [CrossRef] [PubMed]

50. Farris, W.; Mansourian, S.; Chang, Y.; Lindsley, L.; Eckman, E.A.; Frosch, M.P.; Eckman, C.B.; Tanzi, R.E.; Selkoe, D.J.; Guenette, S. Insulin-degrading enzyme regulates the levels of insulin, amyloid beta-protein, and the beta-amyloid precursor protein intracellular domain in vivo. Proc. Natl. Acad. Sci. USA 2003, 100, 4162-4167. [CrossRef] [PubMed]

51. Ittner, L.M.; Ke, Y.D.; Delerue, F.; Bi, M.; Gladbach, A.; van Eersel, J.; Wolfing, H.; Chieng, B.C.; Christie, M.J.; Napier, I.A.; et al. Dendritic function of tau mediates amyloid-beta toxicity in Alzheimer's disease mouse models. Cell 2010, 142, 387-397. [CrossRef] [PubMed]

52. Hong, M.; Lee, V.M. Insulin and insulin-like growth factor-1 regulate tau phosphorylation in cultured human neurons. J. Biol. Chem. 1997, 272, 19547-19553. [CrossRef] [PubMed]

53. Bhat, R.; Xue, Y.; Berg, S.; Hellberg, S.; Ormo, M.; Nilsson, Y.; Radesater, A.C.; Jerning, E.; Markgren, P.O.; Borgegard, T.; et al. Structural insights and biological effects of glycogen synthase kinase 3-specific inhibitor AR-A014418. J. Biol. Chem. 2003, 278, 45937-45945. [CrossRef] [PubMed]

54. Freude, S.; Plum, L.; Schnitker, J.; Leeser, U.; Udelhoven, M.; Krone, W.; Bruning, J.C.; Schubert, M. Peripheral hyperinsulinemia promotes tau phosphorylation in vivo. Diabetes 2005, 54, 3343-3348. [CrossRef] [PubMed]

55. Cheng, C.M.; Tseng, V.; Wang, J.; Wang, D.; Matyakhina, L.; Bondy, C.A. Tau is hyperphosphorylated in the insulin-like growth factor-I null brain. Endocrinology 2005, 146, 5086-5091. [CrossRef] [PubMed] 
56. Phiel, C.J.; Wilson, C.A.; Lee, V.M.; Klein, P.S. GSK-3alpha regulates production of Alzheimer's disease amyloid-beta peptides. Nature 2003, 423, 435-439. [CrossRef] [PubMed]

57. Sims-Robinson, C.; Kim, B.; Rosko, A.; Feldman, E.L. How does diabetes accelerate Alzheimer disease pathology? Nat. Rev. Neurol. 2010, 6, 551-559. [CrossRef] [PubMed]

58. De la Monte, S.M.; Chen, G.J.; Rivera, E.; Wands, J.R. Neuronal thread protein regulation and interaction with microtubule-associated proteins in SH-Sy5y neuronal cells. Cell. Mol. Life Sci. CMLS 2003, 60, 2679-2691. [CrossRef] [PubMed]

59. Bedse, G.; Di Domenico, F.; Serviddio, G.; Cassano, T. Aberrant insulin signaling in Alzheimer's disease: Current knowledge. Front. Neurosci. 2015, 9, 204. [CrossRef] [PubMed]

60. Zlokovic, B.V. Neurovascular pathways to neurodegeneration in Alzheimer's disease and other disorders. Nat. Rev. Neurosci. 2011, 12, 723-738. [CrossRef] [PubMed]

61. Kahn, A.M.; Husid, A.; Allen, J.C.; Seidel, C.L.; Song, T. Insulin acutely inhibits cultured vascular smooth muscle cell contraction by a nitric oxide synthase-dependent pathway. Hypertension 1997, 30, 928-933. [CrossRef] [PubMed]

62. Bhamra, M.S.; Ashton, N.J. Finding a pathological diagnosis for Alzheimer's disease: Are inflammatory molecules the answer? Electrophoresis 2012, 33, 3598-3607. [CrossRef] [PubMed]

63. Mushtaq, G.; Khan, J.A.; Kumosani, T.A.; Kamal, M.A. Alzheimer's disease and type 2 diabetes via chronic inflammatory mechanisms. Saudi J. Biol. Sci. 2015, 22, 4-13. [CrossRef] [PubMed]

64. Fishel, M.A.; Watson, G.S.; Montine, T.J.; Wang, Q.; Green, P.S.; Kulstad, J.J.; Cook, D.G.; Peskind, E.R.; Baker, L.D.; Goldgaber, D.; et al. Hyperinsulinemia provokes synchronous increases in central inflammation and beta-amyloid in normal adults. Arch. Neurol. 2005, 62, 1539-1544. [CrossRef] [PubMed]

65. Sokolova, A.; Hill, M.D.; Rahimi, F.; Warden, L.A.; Halliday, G.M.; Shepherd, C.E. Monocyte chemoattractant protein-1 plays a dominant role in the chronic inflammation observed in Alzheimer's disease. Brain Pathol. 2009, 19, 392-398. [CrossRef] [PubMed]

66. Nakamura, M.; Watanabe, N. Ubiquitin-like protein MNSFbeta/endophilin II complex regulates Dectin-1-mediated phagocytosis and inflammatory responses in macrophages. Biochem. Biophys. Res. Commun. 2010, 401, 257-261. [CrossRef] [PubMed]

67. Akash, M.S.; Rehman, K.; Chen, S. Role of inflammatory mechanisms in pathogenesis of type 2 diabetes mellitus. J. Cell. Biochem. 2013, 114, 525-531. [CrossRef] [PubMed]

68. Erickson, M.A.; Hansen, K.; Banks, W.A. Inflammation-induced dysfunction of the low-density lipoprotein receptor-related protein-1 at the blood-brain barrier: Protection by the antioxidant N-acetylcysteine. Brain Behav. Immun. 2012, 26, 1085-1094. [CrossRef] [PubMed]

69. Matrone, C.; Djelloul, M.; Taglialatela, G.; Perrone, L. Inflammatory risk factors and pathologies promoting Alzheimer's disease progression: Is RAGE the key? Histol. Histopathol. 2015, 30, 125-139. [CrossRef] [PubMed]

70. Munch, G.; Schinzel, R.; Loske, C.; Wong, A.; Durany, N.; Li, J.J.; Vlassara, H.; Smith, M.A.; Perry, G.; Riederer, P. Alzheimer's disease-Synergistic effects of glucose deficit, oxidative stress and advanced glycation endproducts. J. Neural Trans. 1998, 105, 439-461. [CrossRef] [PubMed]

71. Deane, R.; Du Yan, S.; Submamaryan, R.K.; LaRue, B.; Jovanovic, S.; Hogg, E.; Welch, D.; Manness, L.; Lin, C.; $\mathrm{Yu}$, J.; et al. RAGE mediates amyloid-beta peptide transport across the blood-brain barrier and accumulation in brain. Nat. Med. 2003, 9, 907-913. [CrossRef] [PubMed]

72. Chiang, M.C.; Cheng, Y.C.; Chen, S.J.; Yen, C.H.; Huang, R.N. Metformin activation of AMPK-dependent pathways is neuroprotective in human neural stem cells against Amyloid-beta-induced mitochondrial dysfunction. Exp. Cell Res. 2016, 347, 322-331. [CrossRef] [PubMed]

73. Chung, M.M.; Chen, Y.L.; Pei, D.; Cheng, Y.C.; Sun, B.; Nicol, C.J.; Yen, C.H.; Chen, H.M.; Liang, Y.J.; Chiang, M.C. The neuroprotective role of metformin in advanced glycation end product treated human neural stem cells is AMPK-dependent. Biochim. Biophys. Acta 2015, 1852, 720-731. [CrossRef] [PubMed]

74. Gupta, A.; Bisht, B.; Dey, C.S. Peripheral insulin-sensitizer drug metformin ameliorates neuronal insulin resistance and Alzheimer's-like changes. Neuropharmacology 2011, 60, 910-920. [CrossRef] [PubMed]

75. Kickstein, E.; Krauss, S.; Thornhill, P.; Rutschow, D.; Zeller, R.; Sharkey, J.; Williamson, R.; Fuchs, M.; Kohler, A.; Glossmann, H.; et al. Biguanide metformin acts on tau phosphorylation via mTOR/protein phosphatase 2A (PP2A) signaling. Proc. Natl. Acad. Sci. USA 2010, 107, 21830-21835. [CrossRef] [PubMed] 
76. Li, J.; Deng, J.; Sheng, W.; Zuo, Z. Metformin attenuates Alzheimer's disease-like neuropathology in obese, leptin-resistant mice. Pharmacol. Biochem. Behav. 2012, 101, 564-574. [CrossRef] [PubMed]

77. Chen, Y.; Zhou, K.; Wang, R.; Liu, Y.; Kwak, Y.D.; Ma, T.; Thompson, R.C.; Zhao, Y.; Smith, L.; Gasparini, L.; et al. Antidiabetic drug metformin (GlucophageR) increases biogenesis of Alzheimer's amyloid peptides via up-regulating BACE1 transcription. Proc. Natl. Acad. Sci. USA 2009, 106, 3907-3912. [CrossRef] [PubMed]

78. Ng, T.P.; Feng, L.; Yap, K.B.; Lee, T.S.; Tan, C.H.; Winblad, B. Long-term metformin usage and cognitive function among older adults with diabetes. J. Alzheimer's Dis. JAD 2014, 41, 61-68. [CrossRef] [PubMed]

79. Guo, M.; Mi, J.; Jiang, Q.M.; Xu, J.M.; Tang, Y.Y.; Tian, G.; Wang, B. Metformin may produce antidepressant effects through improvement of cognitive function among depressed patients with diabetes mellitus. Clin. Exp. Pharmacol. Physiol. 2014, 41, 650-656. [CrossRef] [PubMed]

80. Herath, P.M.; Cherbuin, N.; Eramudugolla, R.; Anstey, K.J. The Effect of Diabetes Medication on Cognitive Function: Evidence from the PATH Through Life Study. BioMed Res. Int. 2016, 2016, 7208429. [CrossRef] [PubMed]

81. Moore, E.M.; Mander, A.G.; Ames, D.; Kotowicz, M.A.; Carne, R.P.; Brodaty, H.; Woodward, M.; Boundy, K.; Ellis, K.A.; Bush, A.I.; et al. Increased risk of cognitive impairment in patients with diabetes is associated with metformin. Diabetes Care 2013, 36, 2981-2987. [CrossRef] [PubMed]

82. Osborne, C.; West, E.; Nolan, W.; McHale-Owen, H.; Williams, A.; Bate, C. Glimepiride protects neurons against amyloid-beta-induced synapse damage. Neuropharmacology 2016, 101, 225-236. [CrossRef] [PubMed]

83. Alp, H.; Varol, S.; Celik, M.M.; Altas, M.; Evliyaoglu, O.; Tokgoz, O.; Tanriverdi, M.H.; Uzar, E. Protective effects of beta glucan and gliclazide on brain tissue and sciatic nerve of diabetic rats induced by streptozosin. Exp. Diabetes Res. 2012, 2012, 230342. [CrossRef] [PubMed]

84. Esmaeili, M.H.; Bahari, B.; Salari, A.A. ATP-sensitive potassium-channel inhibitor glibenclamide attenuates HPA axis hyperactivity, depression- and anxiety-related symptoms in a rat model of Alzheimer's disease. Brain Res. Bull. 2018, 137, 265-276. [CrossRef] [PubMed]

85. Hsu, C.C.; Wahlqvist, M.L.; Lee, M.S.; Tsai, H.N. Incidence of dementia is increased in type 2 diabetes and reduced by the use of sulfonylureas and metformin. J. Alzheimer's Dis. JAD 2011, 24, 485-493. [CrossRef] [PubMed]

86. Landreth, G. Therapeutic use of agonists of the nuclear receptor PPARgamma in Alzheimer's disease. Curr. Alzheimer Res. 2007, 4, 159-164. [CrossRef] [PubMed]

87. Heneka, M.T.; Sastre, M.; Dumitrescu-Ozimek, L.; Hanke, A.; Dewachter, I.; Kuiperi, C.; O’Banion, K.; Klockgether, T.; Van Leuven, F.; Landreth, G.E. Acute treatment with the PPARgamma agonist pioglitazone and ibuprofen reduces glial inflammation and Abeta1-42 levels in APPV717I transgenic mice. Brain J. Neurol. 2005, 128, 1442-1453. [CrossRef] [PubMed]

88. Yu, Y.; Li, X.; Blanchard, J.; Li, Y.; Iqbal, K.; Liu, F.; Gong, C.X. Insulin sensitizers improve learning and attenuate tau hyperphosphorylation and neuroinflammation in 3xTg-AD mice. J. Neural Trans. 2015, 122, 593-606. [CrossRef] [PubMed]

89. Fernandez-Martos, C.M.; Atkinson, R.A.K.; Chuah, M.I.; King, A.E.; Vickers, J.C. Combination treatment with leptin and pioglitazone in a mouse model of Alzheimer's disease. Alzheimer's Dement. 2017, 3, 92-106. [CrossRef] [PubMed]

90. Sato, T.; Hanyu, H.; Hirao, K.; Kanetaka, H.; Sakurai, H.; Iwamoto, T. Efficacy of PPAR-gamma agonist pioglitazone in mild Alzheimer disease. Neurobiol. Aging 2011, 32, 1626-1633. [CrossRef] [PubMed]

91. Cheng, H.; Shang, Y.; Jiang, L.; Shi, T.L.; Wang, L. The peroxisome proliferators activated receptor-gamma agonists as therapeutics for the treatment of Alzheimer's disease and mild-to-moderate Alzheimer's disease: A meta-analysis. Int. J. Neurosci. 2016, 126, 299-307. [CrossRef] [PubMed]

92. Holscher, C. The role of GLP-1 in neuronal activity and neurodegeneration. Vitam. Horm. 2010, 84, 331-354. [CrossRef] [PubMed]

93. Hunter, K.; Holscher, C. Drugs developed to treat diabetes, liraglutide and lixisenatide, cross the blood brain barrier and enhance neurogenesis. BMC Neurosci. 2012, 13, 33. [CrossRef] [PubMed]

94. McClean, P.L.; Holscher, C. Liraglutide can reverse memory impairment, synaptic loss and reduce plaque load in aged APP/PS1 mice, a model of Alzheimer's disease. Neuropharmacology 2014, 76 Pt A, 57-67. [CrossRef] 
95. Hansen, H.H.; Barkholt, P.; Fabricius, K.; Jelsing, J.; Terwel, D.; Pyke, C.; Knudsen, L.B.; Vrang, N. The GLP-1 receptor agonist liraglutide reduces pathology-specific tau phosphorylation and improves motor function in a transgenic hTauP301L mouse model of tauopathy. Brain Res. 2016, 1634, 158-170. [CrossRef] [PubMed]

96. Gejl, M.; Gjedde, A.; Egefjord, L.; Moller, A.; Hansen, S.B.; Vang, K.; Rodell, A.; Braendgaard, H.; Gottrup, H.; Schacht, A.; et al. In Alzheimer's Disease, 6-Month Treatment with GLP-1 Analog Prevents Decline of Brain Glucose Metabolism: Randomized, Placebo-Controlled, Double-Blind Clinical Trial. Front. Aging Neurosci. 2016, 8, 108. [CrossRef] [PubMed]

97. Kosaraju, J.; Gali, C.C.; Khatwal, R.B.; Dubala, A.; Chinni, S.; Holsinger, R.M.; Madhunapantula, V.S.; Muthureddy Nataraj, S.K.; Basavan, D. Saxagliptin: A dipeptidyl peptidase-4 inhibitor ameliorates streptozotocin induced Alzheimer's disease. Neuropharmacology 2013, 72, 291-300. [CrossRef] [PubMed]

98. Kosaraju, J.; Murthy, V.; Khatwal, R.B.; Dubala, A.; Chinni, S.; Muthureddy Nataraj, S.K.; Basavan, D. Vildagliptin: An anti-diabetes agent ameliorates cognitive deficits and pathology observed in streptozotocin-induced Alzheimer's disease. J. Pharm. Pharmacol. 2013, 65, 1773-1784. [CrossRef] [PubMed]

99. Kornelius, E.; Lin, C.L.; Chang, H.H.; Li, H.H.; Huang, W.N.; Yang, Y.S.; Lu, Y.L.; Peng, C.H.; Huang, C.N. DPP-4 Inhibitor Linagliptin Attenuates Abeta-induced Cytotoxicity through Activation of AMPK in Neuronal Cells. CNS Neurosci. Ther. 2015, 21, 549-557. [CrossRef] [PubMed]

100. Rizzo, M.R.; Barbieri, M.; Boccardi, V.; Angellotti, E.; Marfella, R.; Paolisso, G. Dipeptidyl peptidase-4 inhibitors have protective effect on cognitive impairment in aged diabetic patients with mild cognitive impairment. J. Gerontol. Ser. A Biol. Sci. Med. Sci. 2014, 69, 1122-1131. [CrossRef] [PubMed]

101. Kern, W.; Peters, A.; Fruehwald-Schultes, B.; Deininger, E.; Born, J.; Fehm, H.L. Improving influence of insulin on cognitive functions in humans. Neuroendocrinology 2001, 74, 270-280. [CrossRef] [PubMed]

102. Freiherr, J.; Hallschmid, M.; Frey, W.H., 2nd; Brunner, Y.F.; Chapman, C.D.; Holscher, C.; Craft, S.; De Felice, F.G.; Benedict, C. Intranasal insulin as a treatment for Alzheimer's disease: A review of basic research and clinical evidence. CNS Drugs 2013, 27, 505-514. [CrossRef] [PubMed]

103. Plum, L.; Schubert, M.; Bruning, J.C. The role of insulin receptor signaling in the brain. Trends Endocrinol. Metab. TEM 2005, 16, 59-65. [CrossRef] [PubMed]

104. Craft, S.; Claxton, A.; Baker, L.D.; Hanson, A.J.; Cholerton, B.; Trittschuh, E.H.; Dahl, D.; Caulder, E.; Neth, B.; Montine, T.J.; et al. Effects of Regular and Long-Acting Insulin on Cognition and Alzheimer's Disease Biomarkers: A Pilot Clinical Trial. J. Alzheimer's Dis. JAD 2017, 57, 1325-1334. [CrossRef] [PubMed]

105. Labuzek, K.; Suchy, D.; Gabryel, B.; Bielecka, A.; Liber, S.; Okopien, B. Quantification of metformin by the HPLC method in brain regions, cerebrospinal fluid and plasma of rats treated with lipopolysaccharide. Pharmacol. Rep. 2010, 62, 956-965. [CrossRef]

106. Cheng, C.; Lin, C.H.; Tsai, Y.W.; Tsai, C.J.; Chou, P.H.; Lan, T.H. Type 2 diabetes and antidiabetic medications in relation to dementia diagnosis. J. Gerontol. Ser. A Biol. Sci. Med. Sci. 2014, 69, 1299-1305. [CrossRef] [PubMed]

107. Luchsinger, J.A.; Perez, T.; Chang, H.; Mehta, P.; Steffener, J.; Pradabhan, G.; Ichise, M.; Manly, J.; Devanand, D.P.; Bagiella, E. Metformin in Amnestic Mild Cognitive Impairment: Results of a Pilot Randomized Placebo Controlled Clinical Trial. J. Alzheimer's Dis. JAD 2016, 51, 501-514. [CrossRef] [PubMed]

108. Luchsinger, J.A.; Ma, Y.; Christophi, C.A.; Florez, H.; Golden, S.H.; Hazuda, H.; Crandall, J.; Venditti, E.; Watson, K.; Jeffries, S.; et al. Metformin, Lifestyle Intervention, and Cognition in the Diabetes Prevention Program Outcomes Study. Diabetes Care 2017, 40, 958-965. [CrossRef] [PubMed]

109. Valencia, W.M.; Palacio, A.; Tamariz, L.; Florez, H. Metformin and ageing: Improving ageing outcomes beyond glycaemic control. Diabetologia 2017, 60, 1630-1638. [CrossRef] [PubMed]

110. Imfeld, P.; Bodmer, M.; Jick, S.S.; Meier, C.R. Metformin, other antidiabetic drugs, and risk of Alzheimer's disease: A population-based case-control study. J. Am. Geriatr. Soc. 2012, 60, 916-921. [CrossRef] [PubMed]

111. Geldmacher, D.S.; Fritsch, T.; McClendon, M.J.; Landreth, G. A randomized pilot clinical trial of the safety of pioglitazone in treatment of patients with Alzheimer disease. Arch. Neurol. 2011, 68, 45-50. [CrossRef] [PubMed]

112. Femminella, G.D.; Bencivenga, L.; Petraglia, L.; Visaggi, L.; Gioia, L.; Grieco, F.V.; de Lucia, C.; Komici, K.; Corbi, G.; Edison, P.; et al. Antidiabetic Drugs in Alzheimer's Disease: Mechanisms of Action and Future Perspectives. J. Diabetes Res. 2017, 2017, 7420796. [CrossRef] [PubMed] 
113. Nauck, M.A. Glucagon-like peptide 1 (GLP-1) in the treatment of diabetes. Horm. Metab. Res. 2004, 36, 852-858. [CrossRef] [PubMed]

114. Drucker, D.J.; Sherman, S.I.; Gorelick, F.S.; Bergenstal, R.M.; Sherwin, R.S.; Buse, J.B. Incretin-based therapies for the treatment of type 2 diabetes: Evaluation of the risks and benefits. Diabetes Care 2010, 33, 428-433. [CrossRef] [PubMed]

115. Cork, S.C.; Richards, J.E.; Holt, M.K.; Gribble, F.M.; Reimann, F.; Trapp, S. Distribution and characterisation of Glucagon-like peptide-1 receptor expressing cells in the mouse brain. Mol. Metab. 2015, 4, 718-731. [CrossRef] [PubMed]

116. Liu, X.Y.; Wang, L.X.; Chen, Z.; Liu, L.B. Liraglutide prevents beta-amyloid-induced neurotoxicity in SH-SY5Y cells via a PI3K-dependent signaling pathway. Neurol. Res. 2016, 38, 313-319. [CrossRef] [PubMed]

117. Cai, H.Y.; Wang, Z.J.; Holscher, C.; Yuan, L.; Zhang, J.; Sun, P.; Li, J.; Yang, W.; Wu, M.N.; Qi, J.S. Lixisenatide attenuates the detrimental effects of amyloid beta protein on spatial working memory and hippocampal neurons in rats. Behav. Brain Res. 2017, 318, 28-35. [CrossRef] [PubMed]

118. Isik, A.T.; Soysal, P.; Yay, A.; Usarel, C. The effects of sitagliptin, a DPP-4 inhibitor, on cognitive functions in elderly diabetic patients with or without Alzheimer's disease. Diabetes Res. Clin. Pract. 2017, 123, 192-198. [CrossRef] [PubMed]

119. Shingo, A.S.; Kanabayashi, T.; Kito, S.; Murase, T. Intracerebroventricular administration of an insulin analogue recovers STZ-induced cognitive decline in rats. Behav. Brain Res. 2013, 241, 105-111. [CrossRef] [PubMed]

(C) 2018 by the authors. Licensee MDPI, Basel, Switzerland. This article is an open access article distributed under the terms and conditions of the Creative Commons Attribution (CC BY) license (http:/ / creativecommons.org/licenses/by/4.0/). 